Article

\title{
Evaluation of Nutritional Content in Wild Apricot Fruits for Sustainable Apricot Production
}

\author{
Neva Karatas
}

check for updates

Citation: Karatas, N. Evaluation of Nutritional Content in Wild Apricot Fruits for Sustainable Apricot Production. Sustainability 2022, 14, 1063. https://doi.org/10.3390/ su14031063

Academic Editor: Sezai Ercisli and Marc A. Rosen

Received: 21 December 2021

Accepted: 14 January 2022

Published: 18 January 2022

Publisher's Note: MDPI stays neutral with regard to jurisdictional claims in published maps and institutional affiliations.

Copyright: (C) 2022 by the author. Licensee MDPI, Basel, Switzerland. This article is an open access article distributed under the terms and conditions of the Creative Commons Attribution (CC BY) license (https:/ / creativecommons.org/licenses/by/ $4.0 /)$.
Department of Nutrition and Dietetics, Faculty of Health Sciences, Ataturk University, Erzurum 25240, Turkey; ngungor@atauni.edu.tr; Tel.: +90-533-486-0103

\begin{abstract}
Apricot (Prunus armeniaca L.) trees are common from Asia to North America and have been used for delicious and nutritious fruits for centuries. Wild apricot trees show great environment plasticity and are free of pest and disease traits, both of which are important for sustainable apricot production. However, wild apricots are more common in Asia and North African countries. Wild apricot trees and fruits show great variability due to seed propagation characteristics. Seeds of wild apricots are used as rootstocks for apricot cultivars, in particular in main apricot producer countries such as Turkey, Uzbekistan, and Iran. Fruits of wild apricots are also an important food in wild apricot growing countries and add value as a sustainable nutrition source. In the present study, a total of 14 wild apricots widely grown in inner Anatolia were characterized by morphological (fruit weight, flesh/seed ratio, fruit firmness, and color index), nutritional (individual sugars and organic acids) and nutraceutical (total phenolic, total flavonoids, total carotenoid, and antioxidant activity) features. The obtained results showed that wild apricot genotypes differed from each other for most of the morphological, nutritional, and nutraceutical characteristics. The genotypes were found pestand disease-free and had fruit weight, flesh/seed ratio, and fruit firmness of between 18.24 and $27.54 \mathrm{~g} ; 8.96$ and 12.44; and 4.05 and $6.03 \mathrm{~kg} / \mathrm{cm}^{2}$, respectively. Citric acid was the dominant organic acid for fruits of all wild apricot genotypes, and ranged from 923 to $1224 \mathrm{mg} / 100 \mathrm{~g}$. Sucrose was the highest soluble sugar in fruits for all wild apricots, and ranged from between 6.80 and $8.33 \mathrm{~g} / 100 \mathrm{~g}$. Moreover, the level of nutraceutical parameters also varied among genotypes and high amounts of total phenol and antioxidant activity were obtained in fruit extracts of IA8 genotype as $81.4 \mathrm{mg}$ gallic acid equivalent per $100 \mathrm{~g}$ and $2.44 \mu \mathrm{moL}$ trolox equivalent per $\mathrm{g}$, respectively. Different wild apricot genotypes are rich in certain nutritional and nutraceutical compounds, with significant variations in their levels being observed. The aim of the study was to evaluate fruits of wild apricot genotypes in terms of their total phenolics, antioxidants, and other bioactive compounds for use in future breeding programs and sustainable food and pharma industries.
\end{abstract}

Keywords: wild apricot; diversity; content; nutrition

\section{Introduction}

Fruits have long been consumed due to the benefits they provide to human survival and well-being. They possess a high content of non-nutritive, nutritive, and bioactive compounds such as flavonoids, phenolics, anthocyanins, phenolic acids, and as well as nutritive compounds such as sugars, essential oils, carotenoids, vitamins, and minerals. Different fruit groups have distinct flavors and taste, excellent medicinal value and health care functions as well [1-4].

Prunus is one of the large genera in the plant kingdom and includes about 250 species with important fruit crop representatives such as apricots, almonds, sweet and sour cherries, peaches, and plums [5,6]. They possess long natural propagation periods; mutations have occurred during this long growing period and artificial cultivation leads to a great genetic diversity among cultivars, accessions, and genotypes within Prunus [7-9]. 
The genus representatives can be found in almost every country and continent. They have been recognized not only for their delicious fruits and nuts, but also because of their beneficial properties. To date, numerous cultivars have been phytochemically studied, which has led to the identification of various compounds including flavonoids, phenolic acids, carotenoids, fatty acids, and so on [10-12]. Pharmacological studies on Prunus species have also revealed a variety of bioactive potentials including antioxidant, anti-inflammatory, hypolipidemic, antidiabetic, brain protecting, and other evidence-based uses [13-15].

Apricot trees representatives are largely distributed in many countries and their fruits have been highly cherished for their delicious flavors. Apricot fruits not only have a delicious taste, alluring smell, and vivid colors, but also numerous nutritional properties due to their rich content of vitamin $C, \beta$-carotene, thiamine, riboflavin, niacin, and pantothenic acid, as well as phenols, carotenoids, and tocopherols [16]. The apricot fruit (Prunus armeniaca L.) is considered a good source of total phenolics, flavonoids, and bioactive compounds that have health applications $[9,16]$.

Apricot fruits show a presence of magnesium, calcium, iron, zinc, and copper in larger quantities [17]. The fruits are rich for five different phenolic compounds (chlorogenic acid, syringic acid, quercetin 3-rutinoside, catechin, and epicatechin) [18]. The apricot is known to be a rich source of carotenoids, especially $\beta$-carotene, which represents $50 \%$ of the total carotenoids in the fruit $[19,20]$. Sucrose was the predominant sugar in the apricot fruits at harvest. Quercetin-3-rutinoside may be substantially responsible for the antioxidant capacities of the fruits [21].

The growing of apricots has increased steadily and has reached 3.8 million tons world production, however, the production area remains stable [22]. Among the apricot producers, Turkey dominates world apricot production and has had a yearly average of $600-800$ thousand tons production for a long time, supplying $20 \%$ of world production. The other important producers are Uzbekistan, who supply $13 \%$ of world production, and Iran, who supply $9 \%$ of world production [22].

Wild apricot trees, called Zerdali in Turkey, have diverse fruit and tree characteristics, and are common in most of the apricot growing areas in Turkey [10]. All wild apricot trees are obtained from seeds, namely from an ungrafted situation [23]. There have been no commercial wild apricot orchards in the country from past to date and all wild apricot trees in general grow as solitary trees at the field borders [23,24]. In Turkey, the majority of wild apricot trees are found in middle and eastern Anatolia, including Nigde, Nevsehir, Kayseri, Sivas, Malatya, and Elazig in the country. In particular, wild apricots are abundant in the Aras valley and the Erzincan plain, etc., ranging between 500 and $1650 \mathrm{~m}$ above sea level [25].

The fruits of wild apricot trees are quite variable compared to apricot cultivars and have different fruit shapes, maturation times, fruit colors, tastes, and aroma characteristics. They have sweet-sour taste in general and are very suitable for industrial processing due to a better sugar/acid ratio [10]. Local people prefer wild apricot fruits in Turkey, and seek to obtain very special apricot products such as 'pestil', or 'kome', etc. The people also use it after drying and, due to better rheological and aroma characteristics, process it into jam, fruit juice, and marmalade [23,26,27].

In Turkey, each apricot growing region has its own apricot cultivars, and interregional cultivar transfer generally results in negative adaptation. Because apricot cultivars show low environmental adaptability, the introduction of foreign germplasm may also result in fluctuating or limited yield. However wild apricots have a high environmental plasticity. Thus, wild apricots are very important for sustaining apricot product demand in Turkey $[23,27]$.

Wild apricots are a very important source of adapted plant material, especially when unfavorable climatic and soil conditions are present $[10,23]$. Once established, they are adapted to local dry conditions and their care is easier than their cultivated relatives. There is some indication that new markets for specialty native fruits may be expanding. 
Wild apricot fruits have remarkable roles in and contributions to Turkish diets and food security $[10,23,27]$. The utilization and knowledge of wild apricots as a nutritional source is confined to local people. A detailed literature review into the morphological, nutritional, and nutraceutical content of the wild apricots consumed in the Turkey has not currently been detailed. Thus, this study appears to be the first to validate the detailed morphological, nutritional, and nutraceutical content of selected wild apricot genotypes from Turkey.

\section{Materials and Methods}

\subsection{Plant Samples}

A total 80 fruits per tree were sampled from different parts of wild-grown apricot trees in inner Anatolia in 2018's fruiting season. The examined 10 genotypes were pre-selected according to higher yield, pest- and disease-free trees, and more attractive, larger fruit characteristics. Special attention was given that harvest and fruits were harvested in the same period with the same degree of maturity. Harvested fruits were sorted and cleaned. Mature and healthy fruits were transported to the laboratory and divided into two equal parts for morphological measurements and nutritional and nutraceutical analysis. Figure 1 shows some varieties with different genotypes.
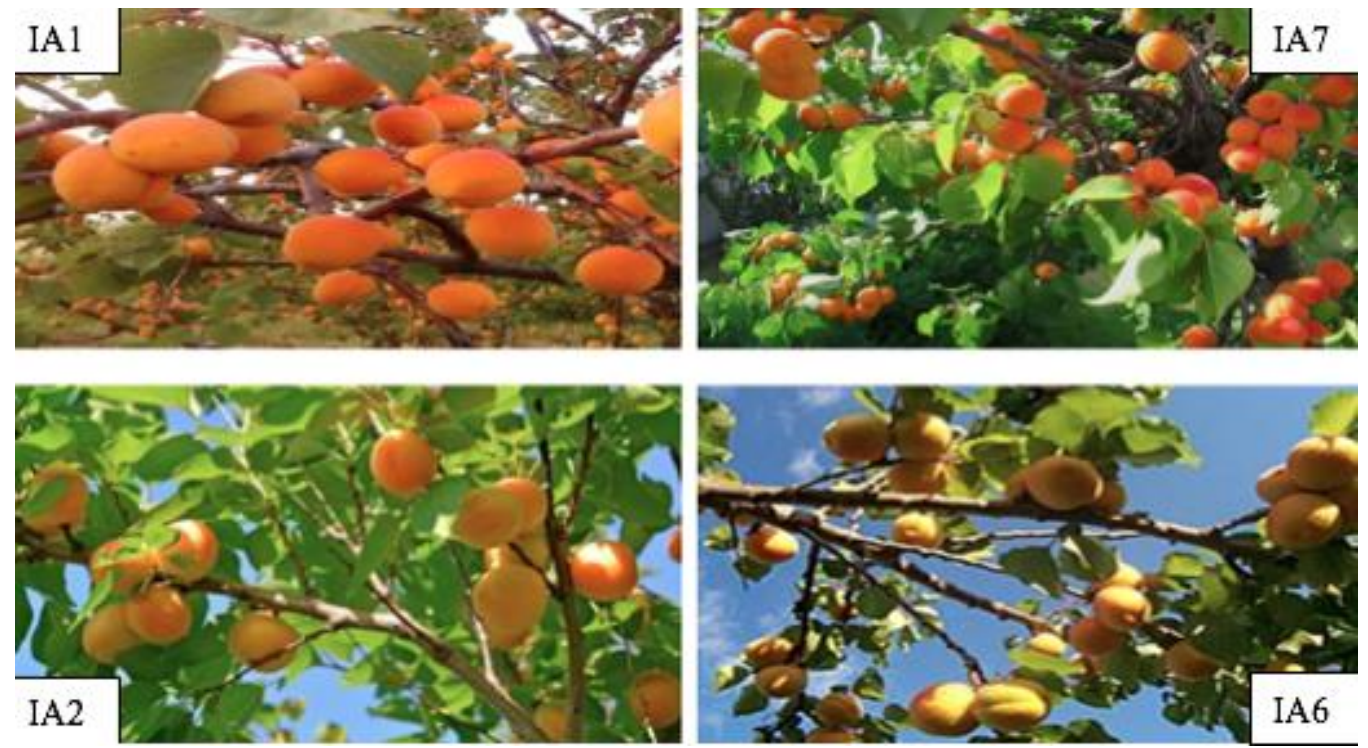

Figure 1. Wild apricot samples (Figures are original).

\subsection{Morphological Parameters}

For morphological measurements (weight, flesh/seed ratio, fruit firmness, and fruit color coordinates), a total of 40 fruits selected among 80 fruits per genotype were used for color coordinates ( $\mathrm{L}$, a and b values). Fruit weight (g) was measured with a digital scale sensitive to $0.01 \mathrm{~g}$ (Scaltec SPB31). Fruit firmness was determined with non-destructive Acoustic Firmness Sensor (Aweta B.V., The Netherlands) expressed as $\mathrm{kg} / \mathrm{cm}^{2}$. Color coordinates $\left(L^{*}, a^{*}\right.$ and $\left.b^{*}\right)$ of fruit skin were determined by a Konica Minolta, CR-400 Plus fruit colorimeter (Konica Minolta, Inc., Chiyoda City, Tokyo, Japan) at four different positions around the equator of the fruits [28].

\subsection{Nutritional and Nutraceutical Composition}

\subsubsection{Sample Preparation and Extraction}

The fruits were introduced to a High-Speed Pulp Ejection Juicer (Omega Products International, Corona, CA, USA), allowing the separation of pomace and juice. The juice was stored at $-80{ }^{\circ} \mathrm{C}$ until its use for nutritional and nutraceutical content. During the analysis, the frozen fruits were taken and thawed to $24-25^{\circ} \mathrm{C}$. A laboratory blender was 
used to homogenize the fruit samples (100 g lots of fruits per genotype) and a single extraction procedure (taking $3 \mathrm{~g}$ aliquots transferred inside tubes and extracted for $1 \mathrm{~h}$ with $20 \mathrm{~mL}$ buffer including acetone, water (deionized), and acetic acid (70:29.5:0.5 v/v) was used [29].

\subsubsection{Organic Acids}

Organic acid composition in fruits of Sekerpare apricot clones was determined by [30]. Organic acid readings were performed by HPLC using the Aminex column (HPX-87 H, $300 \mathrm{~mm} \times 7.8 \mathrm{~mm}$, Bio-Rad Laboratories, Richmond, CA, USA) at 214 and $280 \mathrm{~nm}$ wavelengths in the Agilent package program (Agilent, Santa Clara, CA, USA). Results expressed as $\mathrm{mg} / 100 \mathrm{~g}$.

\subsubsection{Determination of Soluble Sugars}

For soluble sugars (fructose, glucose, and saccharose) analyses, the method of Melgarejo et al. [31] was used. The HPLC analysis was conducted using a PerkinElmer HPLC system with Amino $\mathrm{NH}_{2}$ column (Waters), and $85 \%$ acetonitrile $/ 15 \% \mathrm{H}_{2} \mathrm{O}(v / v)$ as a mobile phase. Refractive index detector (RID) was used. Samples were identified and quantified by standards. Results were expressed as $\mathrm{g} / 100 \mathrm{~g}$ fw. To specify the sweetness perception of 40 fruits per clones, their sweetness indices (SI) were calculated due to Roussos et al. [32]. The SI index considers the relative sweetness as a factor of each of the three sugars measured. It is described in the following Equation (1): where Glu stands for glucose concentration, Fru for fructose concentration, and Sacch stands for saccharose concentration.

$$
S I=1.00 \times \text { Glu }+2.3 \times \text { Fru }+1.35 \times \text { Sacch }
$$

\subsubsection{Total Phenol Content}

The total phenolic content (TPC) of the samples was evaluated using the FolinCiocalteu method according to [33]. The total phenolic content was calculated against the reference standard calibration curve of gallic acid. The TPC was expressed as mg of gallic acid equivalents (GAE) per $100 \mathrm{~g}$ of fresh sample.

\subsubsection{Total Carotenoid Content}

The total carotenoid content was determined by Lichtenthaler [34]. For total carotenoid content, $1 \mathrm{~g}$ of fruit sample was homogenized with $5 \mathrm{~mL}$ of acetone in a cold porcelain mortar in an ice bath. Then $1 \mathrm{~g}$ of anhydrous sodium sulfate $\left(\mathrm{Na}_{2} \mathrm{SO}_{4}\right)$ was added to the homogenate, which was elutriated using a paper filter. The filtered solution was made up to $10 \mathrm{~mL}$ with acetone and centrifuged at $2600 \times \mathrm{g}$ for $10 \mathrm{~min}$. The upper phase was collected and the absorbance of the solution at 662,645 , and $470 \mathrm{~nm}$ was measured. Acetone was used as control. Total carotenoid content was expressed as mg per $100 \mathrm{~g}$ fresh fruit sample.

\subsubsection{Antioxidant Capacity}

TEAC (Trolox Equivalent Antioxidant Capacity) value of each sample was detected according to the method described by Rice-Evans et al. [35]. A total of $7 \mathrm{mM}$ ABTS reagent solutions were prepared and diluted with sodium acetate $\left(\mathrm{C}_{2} \mathrm{H}_{3} \mathrm{NaO}_{2}\right)$ until $0.700 \pm 0.01$ spectrophotometrical absorbance level at $734 \mathrm{~nm}$. Following this, $2.97 \mathrm{~mL}$ buffered solution was mixed with $30 \mu \mathrm{moL}$ fruit extract and kept in the dark at room temperature for $10 \mathrm{~min}$, and measured for their absorbance levels at $734 \mathrm{~nm}$ using spectrophotometer. Obtained results were calculated according to TEAC standard calibration curve and expressed as $\mu \mathrm{moL}$ of trolox equivalent/g fresh fruit weight ( $\mu \mathrm{moL} \mathrm{TE} / \mathrm{g} \mathrm{FW}$ ).

\subsection{Statistical Analysis}

All the experiments were repeated in four replications and the data recorded for different morphological, nutritional, and nutraceutical parameters were analyzed in order to discover which of the genotypes showed a statistically significant difference at $5 \%$ level 
using one-way analysis of variance (ANOVA) and LSD test at $p \leq 0.05$ level of probability with SPSS Software (Release 15.0; SPSS Inc., Chicago, IL, USA).

\section{Results and Discussion}

\subsection{Morphological Features}

Fruit weight, flesh/seed ratio, fruit firmness (Figures 2-4), and color coordinates $(\mathrm{L}, \mathrm{a}, \mathrm{b})$ were used as morphological features of 10 wild apricot genotypes (Table 1 ).

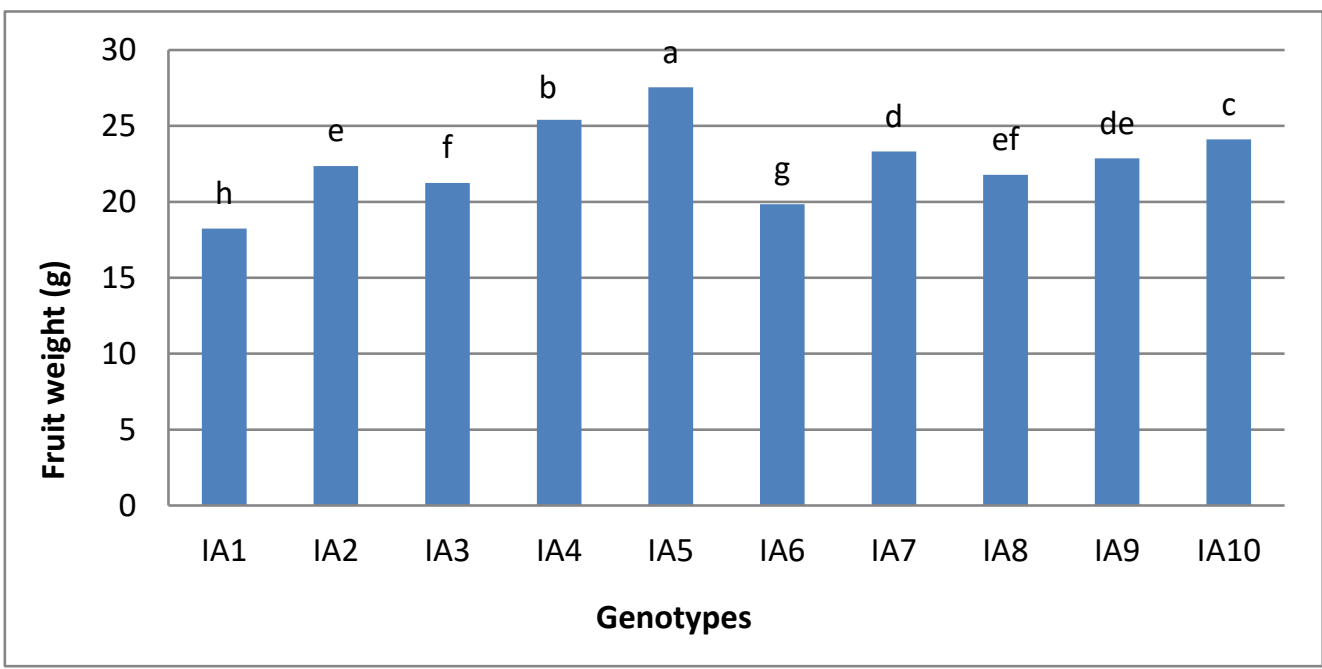

Figure 2. Fruit weight of 10 wild apricot genotypes.

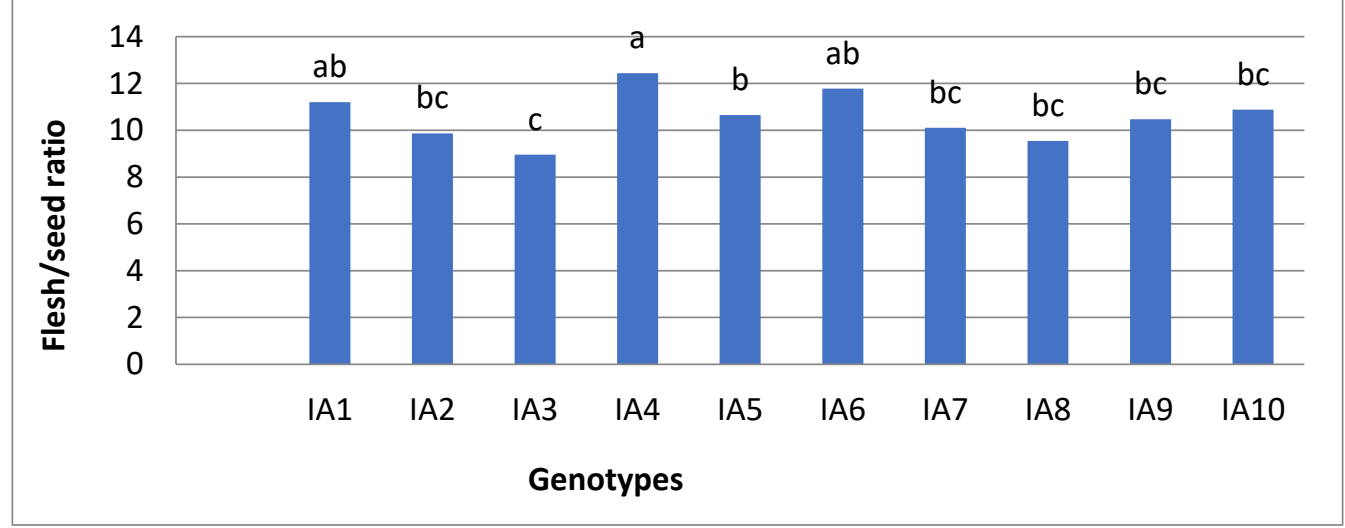

Figure 3. Flesh/seed ratio of 10 wild apricot genotypes.

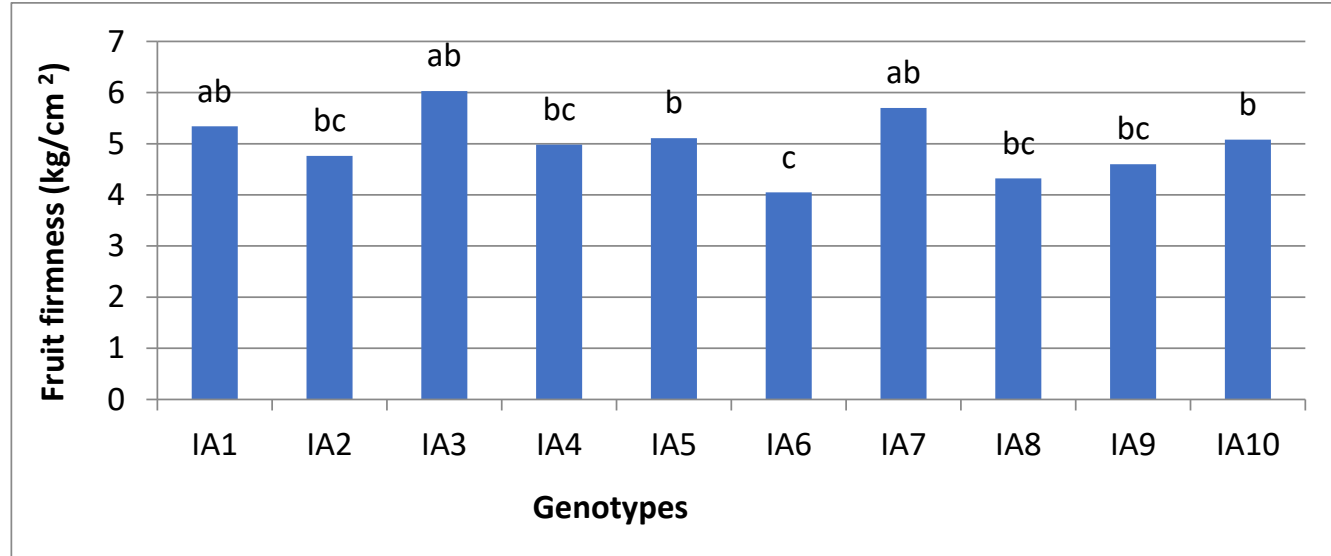

Figure 4. Fruit firmness of 10 wild apricot genotypes. 
Table 1. Fruit skin color parameters of 10 wild apricot genotypes.

\begin{tabular}{|c|c|c|c|c|c|}
\hline Genotypes & $L^{*}$ & $a^{*}$ & $b^{*}$ & Ground Color & $\begin{array}{c}\text { Red Blushed } \\
\text { Skin }\end{array}$ \\
\hline IA1 & $52.72 \mathrm{~cd}$ & $11.37 \mathrm{~cd}$ & $46.11 \mathrm{ab}$ & Orange & Exist \\
\hline IA2 & $56.24 \mathrm{bc}$ & $10.44 \mathrm{~d}$ & $39.11 \mathrm{c}$ & Dark yellow & Absent \\
\hline IA3 & $58.11 \mathrm{~b}$ & $12.24 \mathrm{c}$ & $44.22 \mathrm{~b}$ & Dark yellow & Exist \\
\hline IA4 & $53.44 \mathrm{~cd}$ & $9.44 \mathrm{de}$ & $46.89 \mathrm{ab}$ & Orange & Exist \\
\hline IA5 & $49.14 \mathrm{e}$ & $11.15 \mathrm{~cd}$ & $48.56 \mathrm{a}$ & Dark yellow & Absent \\
\hline IA6 & $60.14 \mathrm{ab}$ & $13.23 \mathrm{bc}$ & $41.23 \mathrm{bc}$ & Yellow & Exist \\
\hline IA7 & $51.27 \mathrm{~d}$ & $9.89 \mathrm{de}$ & $47.55 \mathrm{ab}$ & Orange & Exist \\
\hline IA 8 & $54.32 \mathrm{~cd}$ & $15.33 \mathrm{ab}$ & $42.12 \mathrm{bc}$ & Light orange & Exist \\
\hline IA9 & $61.07 \mathrm{a}$ & $14.12 \mathrm{~b}$ & $40.33 \mathrm{bc}$ & Yellow & Exist \\
\hline IA10 & $55.31 \mathrm{c}$ & $16.32 \mathrm{a}$ & $44.78 \mathrm{~b}$ & Dark orange & Exist \\
\hline
\end{tabular}

Different letters in the same column indicate significant differences $(p<0.05)$ among genotypes.

There were statistically significant differences $(p<0.05)$ among genotypes for fruit weight, flesh/seed ratio, and fruit firmness (Figures 2-4).

The highest fruit weight was observed in genotype IA 5 as $27.54 \mathrm{~g}$, followed by IA4 as $25.40 \mathrm{~g}$ and IA10 as $24.12 \mathrm{~g}$, while the lowest fruit weight was evident in IA1 genotype as $18.24 \mathrm{~g}$ (Figure 2). The obtained fruit weight results were comparable to a previous study conducted in Turkey, because all Turkish apricot cultivars have a relatively small-tomedium fruit weight changing from $25 \mathrm{~g}$ to $40 \mathrm{~g}$ [36-39]. Turkish national apricot cultivars have a relatively small fruit size and previous studies indicated this fact. In the main apricot growing region, namely, Malatya in Turkey, fruit weights were found in the range of 21.16-38.24 g [40]. In another study conducted on 12 wild apricots in the northeastern part of Turkey, fruit weight was reported between 18.56 and $34.28 \mathrm{~g}$ [41]. In another study conducted, Turkish national apricot cultivar Cagataybey and Sekerpare cultivars and fruit weight were found as $25.12 \mathrm{~g}$ and $25.65 \mathrm{~g}$, respectively [42], which is in agreement with the present fruit weight results. Fruit weight is one of the most important properties in markets of fresh apricots and determines consumer acceptance.

Fruit flesh/seed ratio of the 10 wild apricot genotypes were found between 8.96 (IA3) and 12.44 (IA4), respectively (Figure 3). The higher flesh/seed ratio are preferred by both producers and consumers of apricot. In Turkey, the flesh/seed ratio of apricot was reported as 12:02 [10]. Yaman [43] reported the flesh/seed ratio among apricot cultivars between 9.98-16.16, which is in accordance with the present results. Ilhan et al. [41] used 12 wild apricots in northeastern part of Turkey and reported flesh/seed ratio between 8.96-13.30. Akca and Asma [44] found flesh/seed ratio between 12.38 and 16.64 among several clones of cv. Kabaasi in Turkey. In addition, flesh/seed ratios of the foreign apricot cultivars introduced to Turkey and grown in Mediterranean region varied between 8.9 and $21.8[45,46]$. Consumers prefer apricots with a high ratio of flesh and a very small number of seeds.

The fruit firmness values of wild apricot genotypes are in descending order $6.03 \mathrm{~kg} / \mathrm{cm}^{2}($ IA 3$)>5.70 \mathrm{~kg} / \mathrm{cm}^{2}\left(\right.$ IA7) $>5.34 \mathrm{~kg} / \mathrm{cm}^{2}$ (IA1) $>5.11 \mathrm{~kg} / \mathrm{cm}^{2}($ IA 5$)>5.08 \mathrm{~kg} / \mathrm{cm}^{2}$ (IA10) $>4.98 \mathrm{~kg} / \mathrm{cm}^{2}\left(\right.$ IA4) $>4.76 \mathrm{~kg} / \mathrm{cm}^{2}$ (IA2) $>4.60 \mathrm{~kg} / \mathrm{cm}^{2}$ (IA9) $>4.32 \mathrm{~kg} / \mathrm{cm}^{2}$ (IA8) $>$ $4.05 \mathrm{~kg} / \mathrm{cm}^{2}$ (IA6); respectively (Figure 4). Caliskan et al. [47] found the fruit firmness values between $1-4.3 \mathrm{~kg} / \mathrm{cm}^{2}$ for early apricot cultivars in Mediterranean areas in Turkey and present results indicated that wild apricots are suitable for fresh consumption [48].

All wild apricot genotypes were found to be pest- and disease-free. This is very important for sustainable apricot production. Consumers primarily choose unsprayed apricots because of the perceived health benefits, including reduced exposure to pesticide residue as compared to conventionally produced apricots. These genotypes could be important to use in organic apricot production because reduced pesticide exposure for growers and consumers of organic produce can be attributed to prohibition of the use of synthetic pesticides on organic farms, as well the as use of safer alternatives such as biopesticides and biologically derived substances, when needed. 
Table 2 presents $L^{*}, a^{*}$ and $b^{*}$ peel (skin) color coordinates of 10 wild apricots. The all-peel color results indicated statistically significantly differences among genotypes at $p<0.05$ for $L^{*}, a^{*}$ and $b^{*}$ values.

Table 2. Organic acids in fruits of 10 wild apricot genotypes (mg/100 g).

\begin{tabular}{ccccc}
\hline Genotypes & Citric Acid & Malic Acid & Ascorbic Acid & Tartaric Acid \\
\hline IA1 & $1224 \mathrm{ab}$ & $441 \mathrm{ab}$ & $18.4 \mathrm{~b}$ & $4.2 \mathrm{NS}$ \\
IA2 & $1167 \mathrm{ab}$ & $502 \mathrm{ab}$ & $21.5 \mathrm{ab}$ & 4.7 \\
IA3 & $1114 \mathrm{ab}$ & $380 \mathrm{c}$ & $20.6 \mathrm{ab}$ & 5.4 \\
IA4 & $1268 \mathrm{a}$ & $397 \mathrm{bc}$ & $20.2 \mathrm{ab}$ & 3.1 \\
IA5 & $1087 \mathrm{~b}$ & $567 \mathrm{a}$ & $18.8 \mathrm{~b}$ & 6.1 \\
IA6 & $965 \mathrm{bc}$ & $515 \mathrm{ab}$ & $22.2 \mathrm{ab}$ & 5.0 \\
IA7 & $982 \mathrm{bc}$ & $470 \mathrm{~b}$ & $19.6 \mathrm{ab}$ & 6.8 \\
IA8 & $923 \mathrm{c}$ & $495 \mathrm{abc}$ & $23.6 \mathrm{a}$ & 6.2 \\
IA9 & $1035 \mathrm{bc}$ & $544 \mathrm{ab}$ & $19.4 \mathrm{ab}$ & 4.4 \\
IA10 & $996 \mathrm{bc}$ & $450 \mathrm{ab}$ & $21.0 \mathrm{ab}$ & 5.3 \\
\hline Different letters in the same column indicate significant differences $(p<0.05)$ among genotypes; NS: Nonsignificant.
\end{tabular}

The 10 wild apricot fruits showed quite variable $L^{*}, a^{*}$, and $b^{*}$ values. The $L^{*}, a^{*}$, and $b^{*}$ values were observed between 49.14 (IA5)-61.07 (IA9); 9.44 (IA4)-16.32 (IA10) and 39.11 (IA2)-48.56 (IA5), respectively (Table 1). Previously Karaat [16] indicated $L^{*}, a^{*}$, and $b^{*}$ values in apricot fruit as $64.17,14.07$, and 42.27 , respectively, which is in accordance with our results. Karatas and Sengul [49] found $L^{*}, a^{*}$, and $b^{*}$ values of 13 main apricot cultivars grown in Turkey between 48.66-64.70; 8.12-19.41 and 18.06-42.45, respectively. In India $L^{*}$, $a^{*}$, and $b^{*}$ values of six international apricot cultivars were between $52.10-71.51 ; 1.03-39.85$; and 40.56-62.94, respectively [50]. These results reveal that growing conditions and genetic background strongly affect peel color coordinates of apricots.

The most important attribute of any food's appearance is its color, especially when it is directly associated with other food-quality attributes, for example the changes that take place during the ripening of fruit or the loss in color quality as food spoils or becomes stale.

Considering 10 wild apricots, 3 genotypes had dark yellow, 3 genotypes had orange, 2 genotypes had yellow, 1 genotype had light orange, and 1 genotype had dark orange peel color (Table 1). Results implied that yellow and orange was dominant in the apricots, and this is caused by the carotenoids that they contained.

Most of the genotypes (eight) had red blushed skin (Table 1). Because of light penetration, apricot cultivars produce red blushed skin, which is preferred by consumers. Anthocyanins are responsible for the blushed skin of apricots [51]. Apricots with a blush on orange or yellow skin are becoming more and more popular in the market due to their colorful appearance and excellent nutritional value [52].

\subsection{Nutritional Contents}

\subsubsection{Organic Acids}

The literature about the nutritional composition of wild apricots is scarce, particularly regarding organic acids. Table 2 shows the results obtained for the organic acid composition in all of the wild apricot samples, and differentiates the wild apricot samples according to the genotypes considered. Significant differences were observed for all these parameters, except tartaric acid in the mean concentrations or values among the wild apricot genotypes. The wild apricot fruits were slightly acidic compared to cultivated apricots [23].

Wild apricot fruits dominantly included citric acid between 923-1268 mg/100 g, followed by malic acid (380-567 mg/100 g), ascorbic acid (18.4-23.6 mg/100 g), and tartaric acid (3.1-6.8 mg/100 g) (Table 2). Previously, Alajil et al. [50] revealed that citric acid was dominant in apricot fruits and comprised 55\% of the organic acids in apricot fruits and ranged from 550 to $1170 \mathrm{mg} / 100 \mathrm{~g}$, followed by malic acid, which comprised approximately $25 \%$ of the organic acids and ranged from 400 to $1430 \mathrm{mg} / 100 \mathrm{~g}$; these results indicate similarities with this study. In another study, Fan et al. [49] presented that malic acid was 
mainly responsible for sourness of apricots, although malic acid was not the prominent organic acid in all apricot cultivars. Previous studies also indicated the cultivar- and genotype-dependent organic acid content of apricot fruits [50,53-55].

Apricot (Prunus armeniaca L.) is an important temperate fruit crop widely appreciated by consumers for its nutritional and organoleptic properties. The improvement of fruit quality is one of the major breeding objectives for matching a highly competitive market. Among the quality attributes, flavor plays a pivotal role in consumers' degree of liking, which results from a combination of taste and aroma. Apricots' taste primarily depends on sugars and, particularly, organic acids, which affect overall sweetness other than aroma perception. Organic acids' content and profile widely differ between cultivars and the quantitative nature of their inheritance complicates the breeding and selection procedures [56].

\subsubsection{Soluble Sugars and Sweetness Indices}

Table 3 shows soluble sugars of 10 wild-grown apricots. In accordance with the findings of this study, the major sugar was sucrose, followed by glucose and fructose in fruits of the 10 investigated wild apricot genotypes, which varied between $6.80 \mathrm{~g} / 100 \mathrm{~g}$ and $8.33 \mathrm{~g} / 100 \mathrm{~g} ; 1.85 \mathrm{~g} / 100 \mathrm{~g}$ and $3.04 \mathrm{~g} / 100 \mathrm{~g}$; and $0.58 \mathrm{~g} / 100 \mathrm{~g}$ and $1.11 \mathrm{~g} / 100 \mathrm{~g}$, respectively. With respect to the outcomes of the analysis of variance (ANOVA), a significant impact of genotype $(p<0.05)$ has been noted in the sucrose and glucose (Table 3$)$.

Table 3. Soluble sugars (g/100 g) and sweetness indices (SI) in fruits of 10 wild apricot fruits.

\begin{tabular}{ccccc}
\hline Genotypes & Sucrose & Glucose & Fructose & $\begin{array}{c}\text { Sweetness } \\
\text { Indices (SI) }\end{array}$ \\
\hline IA1 & $7.03 \mathrm{de}$ & $2.09 \mathrm{ab}$ & $0.95 \mathrm{NS}$ & $13.77 \mathrm{ab}$ \\
IA2 & $6.80 \mathrm{e}$ & $2.56 \mathrm{ab}$ & 0.77 & $13.51 \mathrm{ab}$ \\
IA3 & $7.44 \mathrm{~cd}$ & $1.85 \mathrm{~b}$ & 0.63 & $13.34 \mathrm{~b}$ \\
IA4 & $8.33 \mathrm{a}$ & $2.44 \mathrm{ab}$ & 0.58 & $15.02 \mathrm{ab}$ \\
IA5 & $6.97 \mathrm{de}$ & $2.95 \mathrm{ab}$ & 1.04 & $14.75 \mathrm{ab}$ \\
IA6 & $7.77 \mathrm{bc}$ & $3.04 \mathrm{a}$ & 0.85 & $15.49 \mathrm{a}$ \\
IA7 & $7.55 \mathrm{~cd}$ & $2.80 \mathrm{ab}$ & 1.11 & $15.54 \mathrm{a}$ \\
IA8 & $7.23 \mathrm{~d}$ & $2.78 \mathrm{ab}$ & 0.67 & $14.08 \mathrm{ab}$ \\
IA9 & $8.02 \mathrm{~b}$ & $2.40 \mathrm{ab}$ & 0.80 & $15.07 \mathrm{ab}$ \\
IA10 & $7.64 \mathrm{c}$ & $2.21 \mathrm{ab}$ & 0.60 & $13.90 \mathrm{ab}$ \\
\hline
\end{tabular}

Different letters in the same column indicate significant differences $(p<0.05)$ among genotypes; NS: Non-Significant.

The results revealed that the genotypes IA4, IA9, and IA10 with $8.33 \mathrm{~g} / 100 \mathrm{~g}, 8.02 \mathrm{~g} / 100 \mathrm{~g}$, and $7.64 \mathrm{~g} / 100 \mathrm{~g}$, respectively, contained the highest percentage of sucrose (Table 3 ). On the other hand, the genotypes IA5 and IA2 with $6.97 \mathrm{~g} / 100 \mathrm{~g}$ and $6.80 \mathrm{~g} / 100 \mathrm{~g}$ indicated the lowest sucrose. Kargi et al. [57] used 21 apricot genotypes grown in Malatya province in Turkey and found that sugar composition of apricot genotypes was different from one genotype to another, and sucrose was the major sugar in apricot fruits, followed by glucose and fructose. In India, Alajil et al. [50] used a number of apricot cultivars and reported sucrose as a major sugar, which accounted for more than $63 \%$ of total sugars and ranged from 4.15 to $10.13 \mathrm{~g} / 100 \mathrm{~g}$; glucose contributed about $22 \%$ of total sugars and ranged from 2.28 to $4.31 \mathrm{~g} / 100 \mathrm{~g}$; and fructose contributed about $15 \%$ of total sugars and ranged from 1.22 to $4.19 \mathrm{~g} / 100 \mathrm{~g}$, which is in accordance with our results. Saridas and Agcam [58] reported sucrose, glucose, and fructose content between 5.33 and 8.57; 1.90 and 2.95; and 0.60 and $0.88 \mathrm{~g} / 100 \mathrm{~g}$, respectively, in apricot cultivars in Eastern Turkey. Imrak et al. [59] found that the dominant sugar in apricot cultivars grown in Mediterranean area was sucrose. Karatas and Sengul [49] reported sucrose as the main sugar in apricot cultivars in Turkey. Su et al. [60] reported that in apricot fruits, sucrose was the main sugar, followed by glucose and fructose. Genard et al. [61] reported the order of individual sugars in apricot fruits depending on their content was in descending order sucrose $>$ glucose $>$ fructose for all cultivars. 
Carbohydrates as one of the main sources of energy as well as their amount of sugar is important in the controlled diet of the diabetic patients [62]; providing information on the sugar composition and content in horticultural plants has gained increasing attention over the years. Furthermore, due to the significant influence of processing practices on different soluble sugars, a need for information on the amount of sugar has gained increasing interest for the food processing industry in order to optimize the processing conditions [63].

The sweetness indices (SI) in fruits of 10 wild-grown apricots were found to be between 13.34 and 15.54 (Table 4). Previously, the sweetness index (SI) ranged from 13.58 to 22.30 in apricot fruits grown in India [50]. In another study conducted in Greece, the sweetness index of early maturated apricot cultivars ranged from 8.16 to 11.25 [32] and in Spain it was found to be between 8.5 and 15.9 in a number of apricot cultivars [64]. Our findings are consistent with the above published studies. The sweetness is important not only to apricot consumers but also for breeders, and it also leads to market acceptance of the apricot fruits $[47,65]$.

Table 4. Nutraceuticals in fruits of 10 wild apricot genotypes (fresh weight basis).

\begin{tabular}{ccccc}
\hline Genotypes & $\begin{array}{c}\text { Total Phenolic } \\
\text { Content } \\
(\mathbf{m g ~ G A E / 1 0 0 ~} \mathbf{g})\end{array}$ & $\begin{array}{c}\text { Total Flavonoids } \\
(\mathbf{m g} \text { CE/100 } \mathbf{g})\end{array}$ & $\begin{array}{c}\text { Total } \\
\text { Carotenoid } \\
\mathbf{( m g / 1 0 0 ~} \mathbf{~})\end{array}$ & $\begin{array}{c}\text { TEAC } \\
(\boldsymbol{\mu m o L} \text { TE/g) }\end{array}$ \\
\hline IA1 & $72.4 \mathrm{bc}$ & $11.2 \mathrm{e}$ & $8.42 \mathrm{bc}$ & $1.95 \mathrm{bc}$ \\
IA2 & $70.1 \mathrm{bc}$ & $9.2 \mathrm{~g}$ & $7.89 \mathrm{bc}$ & $1.85 \mathrm{bc}$ \\
IA3 & $80.8 \mathrm{ab}$ & $14.6 \mathrm{~b}$ & $7.13 \mathrm{c}$ & $2.35 \mathrm{ab}$ \\
IA4 & $74.4 \mathrm{~b}$ & 10.3 & $8.64 \mathrm{~b}$ & $1.90 \mathrm{bc}$ \\
IA5 & $68.3 \mathrm{c}$ & $9.7 \mathrm{f}$ & $7.02 \mathrm{~cd}$ & $1.80 \mathrm{c}$ \\
IA6 & $79.6 \mathrm{ab}$ & $13.7 \mathrm{c}$ & $6.41 \mathrm{~cd}$ & $2.29 \mathrm{ab}$ \\
IA7 & $77.2 \mathrm{ab}$ & $12.3 \mathrm{~d}$ & $9.12 \mathrm{ab}$ & $2.11 \mathrm{~b}$ \\
IA8 & $81.4 \mathrm{a}$ & $15.1 \mathrm{a}$ & $6.67 \mathrm{~cd}$ & $2.44 \mathrm{a}$ \\
IA9 & $69.3 \mathrm{bc}$ & $9.2 \mathrm{~g}$ & $6.15 \mathrm{~d}$ & $1.76 \mathrm{bcd}$ \\
IA10 & $76.0 \mathrm{ab}$ & $11.6 \mathrm{e}$ & $9.93 \mathrm{a}$ & $2.03 \mathrm{bc}$ \\
\hline
\end{tabular}

Different letters in the same column indicate significant differences $(p<0.05)$ among genotypes.

\subsection{Nutraceutical Compositions}

Total Phenolic Content, Total Flavonoids, Total Carotenoids, and Antioxidant Activity

As shown in Table 4, wild apricot fruits statistically differed each other at $p<0.05$ level for total phenolic, total flavonoid, total carotenoid content, and antioxidant activity.

The total phenolic content in fruits of wild apricot genotypes ranged from 68.3 to $81.4 \mathrm{mg}$ GAE/100 $\mathrm{g}$ fresh weight base, representing variation. IA8, IA3, and IA6 had the greatest total phenolic content $(81.4,80.8$ and $79.6 \mathrm{mg}$ GAE/100 $\mathrm{g}$ FW, respectively), while the lower amounts of total phenolic were found in IA2, IA9, and IA5 genotype (70.1, 69.3, and $68.3 \mathrm{mg} \mathrm{GAE} / 100 \mathrm{~g} \mathrm{FW}$, respectively) (Table 4).

In Pakistan, higher and quite variable total phenolic contents (50-220 mg GAE/100 g FW) were reported in eight apricot cultivars grown in stress condition [66]. However, in Turkey, the total phenolic content in wild apricots was found to be between 34.2 and $52.8 \mathrm{mg} \mathrm{GAE} / 100 \mathrm{~g}$ [10]. The total phenolic content in a large number of apricot cultivars grown in Hungary ranged from 12.0 to $89.0 \mathrm{mg}$ GAE/100 g [7]. In India, Alajil et al. [50] found cultivar-dependent total phenolic content between 25.31 and $89.95 \mathrm{mg}$ GAE/100 g FW. Phenolic compounds are important plant constituents with redox properties responsible for antioxidant activity [67]. The hydroxyl groups in plant extracts are responsible for facilitating free radical scavenging.

Antiradical activity against $\mathrm{ABTS}^{+}$expressed as TEAC is presented in Table 4. As presented in Table 4, fruit extracts of IA8, IA3, and IA6 genotypes showed the highest activity with values of $2.44,2.35$, and $2.29 \mu \mathrm{moL} \mathrm{TE} / \mathrm{g}$, which did not differ statistically from each other $(p<0.05)$, while the lowest $\mathrm{ABTS}^{+}$scavenging activity was exhibited by IA5 and IA9 fruit extract (1.80 and $1.76 \mu \mathrm{moL} \mathrm{TE} / \mathrm{g})$. In general, a similar trend was observed for total phenolic content and antiradical activity among genotypes (Table 4). Previously, 
similar antiradical activity was reported between 1.36 and $4.55 \mu \mathrm{moL}$ TE/g in a number of apricot cultivars grown in Italy [68]. Horticultural crops rich in antioxidant components and antiradical activity were found to be cultivar-, genotype- and clone-dependent $[68,69]$.

Fruits of ten wild apricot genotypes had a total flavonoid content between 9.2-15.1 mg CE/100 g (Table 4), indicating approximately 1.5 differences between genotypes that have the highest and lowest flavonoid content. Previous studies also indicated quite variable genotype-dependent total flavonoid content. For example, Saeed et al. [66] found a total flavonoid content between $48-382 \mathrm{mg}$ QE/100 $\mathrm{g}$ in apricots. In India, Alajil et al. [50] reported it as being between 5-15 mg CE/100 g, which indicated good agreement with our study. In Italy, Carbone et al. [70] presented total flavonoid content (TFC) in apricot cultivars between 1.9 and $12.0 \mathrm{mg} \mathrm{CE} / 100 \mathrm{~g}$. Wani et al. [71] found TFC values ranging from 12.2 to $36.2 \mathrm{mg} / 100 \mathrm{~g}$ in apricot genotypes grown in India. The fruits of wild apricots revealed the presence of considerable amounts of flavonoids, which supports the antioxidant and nutritional potential of this plant species. In our study, the content of flavonoids differs from one genotype to another.

Total carotenoid content of 10 wild apricot fruits was in the range of $6.15-9.93 \mathrm{mg} / 100 \mathrm{~g}$, and genotypes exhibited statistically significant differences to each other at $p<0.05$ level (Table 4). IA10 and IA9 genotypes characterized the highest $(9.93 \mathrm{mg} / 100 \mathrm{~g}$ ) and lowest $(6.15 \mathrm{mg} / 100 \mathrm{~g})$ total carotenoid values, respectively. The other genotypes' total carotenoid content decreased in the order: IA7 $>$ IA4 $>$ IA1 $>$ IA2 $>$ IA3 $>$ IA5 $>$ IA8. There was discovered a 1.5-fold difference in TEAC obtained from wild apricot fruit extracts (Table 4). In Spain, Ruiz et al. [19] reported a total carotenoid content between 1.5 and $16.5 \mathrm{mg} / 100 \mathrm{~g}$ among diverse apricot cultivars. In Israel, Shemesh et al. [20] reported it between 0.5 and $9.5 \mathrm{mg} / 100 \mathrm{~g}$ among apricot cultivars. In Turkey, Gecer et al. [10] reported total carotenoid content between 1.1 and $12.5 \mathrm{mg} / 100 \mathrm{~g}$ in wild apricots. The above studies are in agreement with present results. Apricots are high in carotenoids, which influence the color and visual appearance of the fruit; the color of the fruit can vary from yellow to orange depending on the carotenoids content $[21,67]$.

Previous studies conducted on different horticultural plants indicate a great biochemical difference among genotypes [72-79].

\section{Conclusions}

As a conclusion, the present study provides one of the first detailed data describing the morphological, nutritional, and nutraceutical characteristics of a large number of diverse wild apricot genotypes sampled from inner Anatolia. The results indicated considerable variation in most of the phytochemical and fruit quality characters in wild apricot genotypes. The genotypes IA5 and IA4 had the highest fruit weight and IA8 and IA5 had the highest total phenolic content and antiradical activity. Results also indicated the importance of wild apricots in more sustainable apricot production due to their pest- and disease-free characteristics. Therefore, this work represents a valuable source of genotypes to be used in apricot breeding programs. The findings contribute to the improvement of an integrated, effective, and sustainable strategy for apricots.

Funding: No external funding for this research.

Institutional Review Board Statement: Not applicable.

Informed Consent Statement: Not applicable.

Data Availability Statement: All new research data were presented in this contribution.

Conflicts of Interest: The author declares that he has no conflict of interest.

\section{References}

1. Sahin, U.; Anapali, O.; Ercisli, S. Physico-chemical and physical properties of some substrates used in horticulture. Gartenbauwissenschaft 2002, 67, 55-60. 
2. Gundogdu, M.; Ozrenk, K.; Ercisli, S.; Kan, T.; Kodad, O.; Hegedus, A. Organic acids, sugars, vitamin C content and some pomological characteristics of eleven hawthorn species (Crataegus spp.) from Turkey. Biol. Res. 2014, 47, 21. [CrossRef]

3. Engin, S.P.; Mert, C. The effects of harvesting time on the physicochemical components of aronia berry. Turk. J. Agric. For. 2020, 44, 361-370. [CrossRef]

4. Kaskoniene, V.; Bimbiraite-Surviliene, K.; Kaskonas, P.; Tiso, N.; Cesoniene, L.; Daubaras, R.; Maruska, A.S. Changes in the biochemical compounds of Vaccinium myrtillus, Vaccinium vitis-idaea, and forest litter collected from various forest types. Turk. J. Agric. For. 2020, 44, 557-566. [CrossRef]

5. Milosevic, T.; Milosevic, N.; Glisic, I. Early tree performances, precocity and fruit quality attributes of newly introduced apricot cultivars grown under western Serbian conditions. Turk. J. Agric. For. 2021, 45, 819-833. [CrossRef]

6. Gurrieri, F.; Audergon, J.M.; Albagnac, G.; Reich, M. Soluble sugars and carboxylic acids in ripe apricot fruit as parameters for distinguishing different cultivars. Euphytica 2001, 117, 183-189. [CrossRef]

7. Hegedus, A.; Engel, R.; Abranko, L.; Balogh, E.; Blazovics, A.; Herman, R.; Halasz, J.; Ercisli, S.; Pedryc, A.; Stefanovits-Banyai, E. Antioxidant and antiradical capacities in apricot (Prunus armeniaca L.) fruits: Variation from genotypes, years, and analytical methods. J. Food Sci. 2010, 75, C722-C730. [CrossRef]

8. Mratinić, E.; Popovski, B.; Milošević, T.; Popovska, M. Evaluation of apricot fruit quality and correlations between physical and chemical attributes. Czech. J. Food Sci. 2011, 29, 161-170. [CrossRef]

9. Ricci, A.; Sabbadini, S.; Prieto, H.; Padilla, I.M.; Dardick, C.; Li, Z.; Scorza, R.; Limera, C.; Mezzetti, B.; Perez-Jimenez, M.; et al. Genetic transformation in peach (Prunus persica L.): Challenges and ways forward. Plants 2020, 9, 971. [CrossRef]

10. Gecer, M.K.; Kan, T.; Gundogdu, M.; Ercisli, S.; Ilhan, G.; Sagbas, H.I. Physicochemical characteristics of wild and cultivated apricots (Prunus armeniaca L.) from Aras valley in Turkey. Genet. Resour. Crop Evol. 2020, 67, 935-945. [CrossRef]

11. Barreca, D.; Nabavi, S.M.; Sureda, A.; Rasekhian, M.; Raciti, R.; Silva, A.S.; Annunziata, G.; Arnone, A.; Tenore, G.C.; Süntar, I.; et al. Almonds (Prunus dulcis Mill. DA webb): A source of nutrients and health-promoting compounds. Nutrients 2020, 12, 672. [CrossRef]

12. Veerappan, K.; Natarajan, S.; Chung, H.; Park, J. Molecular insights of fruit quality traits in peaches, Prunus persica. Plants 2021, 10, 2191. [CrossRef] [PubMed]

13. Campbell, O.E.; Merwin, I.A.; Padilla-Zakour, O.I. Characterization and the effect of maturity at harvest on the phenolic and carotenoid content of Northeast USA apricot (Prunus armeniaca) varieties. J. Agric. Food Chem. 2013, 61, 12700-12710. [CrossRef]

14. Wojdyło, A.; Nowicka, P.; Laskowski, P.; Oszmiański, J. Evaluation of sour cherry (Prunus cerasus L.) fruits for their polyphenol content, antioxidant properties, and nutritional components. J. Agric. Food Chem. 2014, 62, 12332-12345. [CrossRef] [PubMed]

15. McCullough, M.L.; Peterson, J.J.; Patel, R.; Jacques, P.F.; Shah, R.; Dwyer, J.T. Flavonoid intake and cardiovascular disease mortality in a prospective cohort of US adults. Am. J. Clin. Nutr. 2012, 95, 454-464. [CrossRef] [PubMed]

16. Karaat, F.E. Variation and Heritability of Phytochemical Characters in Some Apricot Cultivars and Hybrids; Graduate School of Natural and Applied Sciences, Department of Agricultural Genetic Engineering, Nigde Omer Halisdemir University: Nigde, Turkey, 2018 ; p. 88.

17. Singh, M.; Suman, S.; Shukla, Y. New enlightenment of skin cancer chemoprevention through phytochemicals: In vitro and in vivo studies and the underlying mechanisms. BioMed Res. Int. 2014, 2014, 243452. [CrossRef]

18. Rodríguez-Morató, J.; Xicota, L.; Fitó, M.; Farré, M.; Dierssen, M.; De la Torre, R. Potential role of olive oil phenolic compounds in the prevention of neurodegenerative diseases. Molecules 2015, 20, 4655-4680. [CrossRef] [PubMed]

19. Ruiz, D.; Egea, J.; Tomás-Barberán, F.A.; Gil, M.I. Carotenoids from new apricot (Prunus armeniaca L.) varieties and their relationship with flesh and skin colour. J. Agric. Food Chem. 2005, 53, 6368-6374. [CrossRef]

20. Shemesh, K.; Zohar, M.; Bar-Yaakov, I.; Hatib, K.; Holland, D.; Isaacson, T. Analysis of carotenoids in fruit of different apricot accessions reveals large variability and highlights apricot as a rich source of phytoene and phytofluene. Fruits 2017, 72, 185-202. [CrossRef]

21. Fratianni, F.; Ombra, M.N.; d'Acierno, A.; Cipriano, L.; Nazzaro, F. Apricots: Biochemistry and functional properties. Curr. Opin. Food Sci. 2018, 19, 23-29. [CrossRef]

22. FAO. Food and Agriculture Organization of the United Nations. 2020. Available online: http://www.fao.org/faostat/en/\#data/ QC (accessed on 18 April 2021).

23. Ercisli, S. Apricot culture in Turkey. Sci. Res. Essays 2009, 4, 715-719.

24. Halász, J.; Hegedüs, A.; Szikriszt, B.; Ercisli, S.; Orhan, E.; Unlu, H.M. The S-genotyping of wild-grown apricots reveals only self-incompatible accessions in the Erzincan region of Turkey. Turk. J. Biol. 2013, 37, 733-740. [CrossRef]

25. Ercisli, S. A short review of the fruit germplasm resources of Turkey. Genet. Resour. Crop Evol. 2004, 51, 419-435. [CrossRef]

26. Bostan, S.Z. Researches on breeding by selection of wild apricot (Prunus armeniaca L.) types in Gumushane province of Turkey. In Proceeding of the 5th National Horticultural Congress, Barapani, India, 18-21 April 2007; Volume 1, pp. 502-510.

27. Pinar, H.; Unlu, M.; Ercisli, S.; Uzun, A.; Bircan, M.; Yilmaz, K.U.; Agar, G. Determination of genetic diversity among wild grown apricots from Sakit valley in Turkey using SRAP markers. J. Appl. Bot. Food Qual. 2013, 86, 55-58.

28. Ozturk, I.; Ercisli, S.; Kalkan, F.; Demir, B. Some chemical and physico-mechanical properties of pear cultivars. Afr. J. Biotechnol. 2009, 8, 687-693.

29. Fogarasi, M.; Socaciu, M.-I.; Sălăgean, C.-D.; Ranga, F.; Fărcaș, A.C.; Socaci, S.A.; Socaciu, C.; Tibulcă, D.; Fogarasi, S.; Semeniuc, C.A. Comparison of different extraction solvents for characterization of antioxidant potential and polyphenolic composition in Boletus edulis and Cantharellus cibarius mushrooms from Romania. Molecules 2021, 26, 7508. [CrossRef] 
30. Akagić, A.; Oras, A.V.; Oručević Žuljević, S.; Spaho, N.; Drkenda, P.; Bijedić, A.; Memić, S.; Hudina, M. Geographic variability of sugars and organic acids in selected wild fruit species. Foods 2020, 9, 462. [CrossRef] [PubMed]

31. Melgarejo, P.; Legua, P.; Martínez-Font, R.; Martínez-Nicolás, J.J.; Sánchez Soriano, J.; Carbonell-Barrachina, Á.A.; Hernández, F. Response of apricot fruit quality to protective netting. Agriculture 2021, 11, 260. [CrossRef]

32. Roussos, P.A.; Sefferou, V.; Denaxa, N.K.; Tsantili, E.; Stathis, V. Apricot (Prunus armeniaca L.) fruit quality attributes and phytochemicals under different crop load. Sci. Hortic. 2011, 129, 472-478. [CrossRef]

33. Rampackova, E.; Göttingerova, M.; Gala, P.; Kiss, T.; Ercisli, S.; Necas, T. Evaluation of protein and antioxidant content in apricot kernels as a sustainable additional source of nutrition. Sustainability 2021, 13, 4742. [CrossRef]

34. Lichtenthaler, H.K. Chlorophylls and carotenoids: Pigments of photosynthetic biomembranes. Methods Enzymol. 1987, 148, 350-382.

35. Evans, R.H.; Van Soestbergen, A.W.; Ristow, K.A. Evaluation of apple juice authenticity of organic acid analysis. J. Assoc. Off. Anal. Chem. 1983, 66, 1517-1520. [CrossRef]

36. Akca, Y.; Askin, A. Clonal selection in apricot cultivar Hacihaliloglu. Acta Hortic. 1995, 384, 169-171. [CrossRef]

37. Asma, B.M.; Ozturk, K. Analysis of morphological, pomological and yield characteristics of some apricot germplasm in Turkey. Genet. Resour. Crop Evol. 2005, 52, 305-313. [CrossRef]

38. Altindag, M.; Sahin, M.; Esitken, A.; Ercisli, S.; Guleryuz, M.; Donmez, M.F.; Sahin, F. Biological control of brown rot (Moniliana laxa Ehr.) on apricot (Prunus armeniaca L. cv. Hacihaliloglu) by Bacillus, Burkholderia and Pseudomonas application under in vitro and in vivo conditions. Biol. Control 2006, 38, 369-372. [CrossRef]

39. Yilmaz, K.U.; Paydas Kargi, S.; Kafkas, S. Morphological diversity of the Turkish apricot (Prunus armeniaca L.) germplasm in the Irano-Caucasian ecogeographical group. Turk. J. Agric. For. 2010, 36, 688-694.

40. Akin, E.B.; Karabulut, I.; Topcu, A. Some compositional properties of main Malatya apricot (Prunus armeniaca L.) varieties. Food Chem. 2008, 107, 939-948. [CrossRef]

41. Ilhan, G.; Sagbas, H.I.; Ercisli, S.; Ozkan, G. Physicochemical characteristics of wild apricots from Northeastern Turkey. Acta Hortic. 2020, 1290, 13-18. [CrossRef]

42. Karaat, F.E.; Serce, S. Total phenolics, antioxidant capacities and pomological characteristics of 12 apricot cultivars grown in Turkey. Adyütayam 2019, 7, 46-60.

43. Yaman, B. The Effects of Mulch Types on Earliness, Yield and Fruit Quality for Apricot. Master's Thesis, Graduate School of Mustafa Kemal University, Hatay, Turkey, 2012; p. 72.

44. Akca, Y.; Asma, B.M. Clonal selection from cv. Kabasi apricot. Turk. J. Agric. For. 1997, 21, 519-521.

45. Polat, A.A.; Yilmaz, M. Investigations on the adaptations of some native and foreign apricot cultivars to Adana ecological conditions. J. Sci. Eng. 1988, 2, 127-146.

46. Polat, A.A.; Durgac, C.; Kamiloglu, O.; Caliskan, O. Investigation on the adaptation of some low-chill apricot cultivars to Kirikhan (Turkey) ecological conditions. Acta Hortic. 2004, 636, 395-400. [CrossRef]

47. Çaliskan, O.; Bayazit, S.; Sumbul, A. Fruit quality and phytochemical attributes of some apricot (Prunus armeniaca L.) cultivars as affected by genotypes and seasons. Not. Bot. Horti Agrobot. Cluj-Napoca 2012, 40, 284-294. [CrossRef]

48. Ruiz, D.; Egea, J. Phenotypic diversity and relationships of fruit quality traits in apricot (Prunus armeniaca L.) germplasm Euphytica 2008, 163, 143-158. [CrossRef]

49. Karatas, N.; Sengul, M. Some important physicochemical and bioactive characteristics of the main apricot cultivars from Turkey. Turk. J. Agric. For. 2020, 44, 651-661. [CrossRef]

50. Alajil, O.; Sagar, V.R.; Kaur, C.; Rudra, S.G.; Sharma, R.R.; Kaushik, R.; Verma, M.K.; Tomar, M.; Kumar, M.; Mekhemar, M. Nutritional and phytochemical traits of apricots (Prunus armeniaca L.) for application in nutraceutical and health industry. Foods 2021, 10, 1344. [CrossRef]

51. Xi, W.; Feng, J.; Liu, Y.; Zhang, S.; Zhao, G. The R2R3-MYB transcription factor PaMYB10 is involved in anthocyanin biosynthesis in apricots and determines red blushed skin. BMC Plant Biol. 2019, 19, 287. [CrossRef] [PubMed]

52. Yuan, H.; Zhang, J.X.; Nageswaran, D.; Li, L. Carotenoid metabolism and regulation in horticultural crops. Hortic. Res. 2015, 2, 15036. [CrossRef] [PubMed]

53. Saridas, M.A.; Agcam, E. Detailed fruit quality contents of 'Teberze' and 'Ağerik' apricot (Prunus armeniaca L.) cultivars grown in Iğdır province. Harran J. Agric. Food Sci. 2021, 25, 214-224.

54. Bae, H.; Yun, S.K.; Yoon, I.K.; Nam, E.Y.; Kwon, J.H. 2014. Assessment of organic acid and sugar composition in apricot, plumcot, plum, and peach during fruit development. J. Food Qual. Appl. Bot. 2014, 87, 24-29.

55. Elmenofy, H.M.; Okba, S.K.; Salama, A.-M.; Alam-Eldein, S.M. Yield, fruit quality, and storability of 'canino' apricot in response to aminoethoxyvinylglycine, salicylic acid, and chitosan. Plants 2021, 10, 1838. [CrossRef]

56. Cirilli, M.; Baccichet, I.; Chiozzotto, R.; Spinardi, A.; Bassi, D. Organic acids content in fruit flesh and skin from a large apricot collection. Acta Hortic. 2020, 1290, 197-200. [CrossRef]

57. Kargi, S.P.; Kafkas, E.; Yilmaz, K.U. Detection of sugar composition of some apricot cultivars by high performance liquid chromatography. Acta Hortic. 2010, 862, 583-586.

58. Okba, S.K.; Mazrou, Y.; Elmenofy, H.M.; Ezzat, A.; Salama, A. New insights of potassium sources impacts as foliar application on "Canino" apricot fruit yield, fruit anatomy, quality and storability. Plants 2021, 10, 1163. [CrossRef] 
59. Imrak, B.A.; Küden, V.; Yurtkulu, E.; Kafkas, S.; Ercişli, S.; Kafkas, E. Evaluation of some phenological and biochemical characteristics of selected new late flowering dried apricot cultivars. Biochem. Genet. 2017, 55, 234-243. [CrossRef] [PubMed]

60. Su, C.; Zheng, X.; Zhang, D.; Chen, Y.; Xiao, J.; He, Y.; Shi, X. Investigation of sugars, organic acids, phenolic compounds, antioxidant activity and the aroma fingerprint of small white apricots grown in Xinjiang. J. Food Sci. 2020, 85, 4300-4311. [CrossRef]

61. Génard, M.; Lescourret, F.; Audergon, J.M.; Reich, M.; Albagnac, G. Modeling the apricot sugar contents in relation to fruit growth. Acta Hortic. 2006, 701, 517-522. [CrossRef]

62. Hecke, K.; Herbinger, K.; Veberic, R.; Trobec, M.; Toplak, H.; Štampar, F.; Keppel, H.; Grill, D. Sugar, acid and phenol contents in apple cultivars from organic and integrated fruit cultivation. Eur. J. Clin. Nutr. 2006, 60, 1136-1140. [CrossRef] [PubMed]

63. Ledbetter, C.; Peterson, S.; Jenner, J. Modification of sugar profiles in California adapted apricots (Prunus armeniaca L.) through breeding with Central Asian germplasm. Euphytica 2006, 148, 251-259. [CrossRef]

64. Bavec, M.; Turinek, M.; Grobelnik-Mlakar, S.; Slatnar, A.; Bavec, F. Influence of industrial and alternative farming systems on contents of sugars, organic acids, total phenolic content, and the antioxidant activity of red beet (Beta vulgaris L. ssp. vulgaris Rote Kugel). J. Agric. Food Chem. 2010, 58, 11825-11831. [CrossRef]

65. Schmitzer, V.; Slatnar, A.; Mikulic-Petkovsek, M.; Veberic, R.; Krska, B.; Stampar, F. Comparative study of primary and secondary metabolites in apricot (Prunus armeniaca L.) cultivars. J. Sci. Food Agric. 2011, 91, 860-866. [CrossRef]

66. Saeed, I.; Guo, X.; Azeem, M.; Elshikh, M.S.; Zainab, B.; Ayaz, Z.; You, L.; Alwahibi, M.S.; Abbasi, A.M. Comparative assessment of polyphenolics' content, free radicals' scavenging and cellular antioxidant potential in apricot fruit. J. King Saud Univ.-Sci. 2021, 33, 101459. [CrossRef]

67. Soobrattee, M.A.; Neergheen, V.S.; Luximon-Ramma, A.; Aruoma, O.I.; Bahorun, T. Phenolics as potential antioxidant therapeutic agents: Mechanism and actions. Mutat. Res.-Fundam. Mol. Mutagen. 2005, 579, 200-213. [CrossRef]

68. Leccese, A.; Bartolini, S.; Viti, R. Total antioxidant capacity and phenolics content in fresh apricots. Acta Aliment. 2008, 37, 65-76. [CrossRef]

69. Zia-Ul-Haq, M.; Ahmad, S.; Qayum, M.; Ercisli, S. Compositional studies and antioxidant potential of Albizia lebbeck (L.) Benth Pods and seeds. Turk. J. Biol. 2013, 37, 25-32.

70. Carbone, K.; Ciccoritti, R.; Paliotta, M.; Rosato, T.; Terlizzi, M.; Cipriani, G. Chemometric classification of early-ripening apricot (Prunus armeniaca L.) germplasm based on quality traits, biochemical profiling and in vitro biological activity. Sci. Hortic. 2018, 227, 187-195. [CrossRef]

71. Wani, A.A.; Zargar, S.A.; Malik, A.H.; Kashtwari, M.; Nazir, M.; Khuroo, A.A.; Ahmad, F.; Dar, T.A. Assessment of variability in morphological characters of apricot germplasm of Kashmir, India. Sci. Hortic. 2017, 225, 630-637. [CrossRef]

72. Benjak, A.; Ercisli, S.; Vokurka, A.; Maletic, E.; Pejic, I. Genetic relationships among grapevine cultivars native to Croatia, Greece and Turkey. Vitis 2005, 44, 73-77.

73. Ercisli, S.; Esitken, A.; Turkkal, C.; Orhan, E. The allelopathic effects of juglone and walnut leaf extracts on yield, growth, chemical and PNE composition of strawberry cv. Fern. Plant Soil Environ. 2005, 51, 283-387. [CrossRef]

74. Bolat, I.; Dikilitas, M.; Ercisli, S.; Ikinci, A.; Tonkaz, T. The effect of water stress on some morphological, physiological, and biochemical characteristics and bud success on apple and quince rootstocks. Sci. World J. 2014, 76, 9732. [CrossRef]

75. Dogan, H.; Ercisli, S.; Jurikova, T.; Temim, E.; Leto, A.; Hadziabulic, A.; Tosun, M.; Narmanlioglu, H.K.; Zia-Ul-Haq, M. Physicochemical and antioxidant characteristics of fruits of cape gooseberry (Physalis peruviana L.) from Turkey. Oxid. Commun. 2014, 37, 1005-1014.

76. Dogan, H.; Ercisli, S.; Temim, E.; Hadziabulic, A.; Tosun, M.; Yilmaz, S.O.; Zia-Ul-Haq, M. Diversity of chemical content and biological activity in flower buds of a wide number of wild grown caper (Capparis ovate Desf.) genotypes from Turkey. C. R. Acad. Bulg. Sci. 2014, 67, 1593-1600.

77. Ersoy, N.; Kupe, M.; Sagbas, H.I.; Ercisli, S. Phytochemical diversity among barberry (Berberis vulgaris L.). Not. Bot. Horti Agrobot. Cluj-Napoca 2018, 46, 198-204.

78. Ersoy, N.; Kupe, M.; Gundogdu, M.; Gulce, I.; Ercisli, S. Phytochemical and antioxidant diversity in fruits of currant (Ribes spp.) cultivars. Not. Bot. Horti Agrobot. Cluj-Napoca 2018, 46, 381-387. [CrossRef]

79. Kupe, M. Some ampelographic and biochemical characteristics of local grape accessions from Turkey. Genetika 2020, 52, 513-525. [CrossRef] 